\section{The mind of an unhappy genius}

\section{A. Rupert Hall}

Descartes: An Intellectual Biography. By Stephen Gaukroger. Oxford University Press: 1995. Pp. 499. £25, \$35.

WHAT is an intellectual biography'? It must surely be more than either a lifehistory or an analysis of achievements set out in chronological order, or even a discussion of those features of a person's work that seem to stem directly from his or her experience. To understand Wordsworth's lines "It is a beauteous evening, calm and free/The holy time is quiet as a Nun/Breathless with adoration", we need not only to know of hidden events in the poet's 강 life but also to penetrate some way into his character and such social matters as attitudes to love-children. So intellectual biography is perhaps a richer form when emotional content is high and certainly it requires a range of private material to make the connection between a man or a woman and the work.

We can never know seventeenth-century figures such as Harvey, Descartes or Newton as well as we know Wordsworth. The human materials for biographical depth do not exist. For Descartes (1596-1650), details of the first 30 years of his life are few; thereafter, several volumes of correspondence still leave obscurities in his development and personal relationships with others. We know that he fathered a child of a servant, we suspect that he suffered (especially as a young man) more than one psychological crisis and we may infer (from episodes of unreasonable intellectual jealousy, for example) that he was unstable and insecure: his life was that of an unhappy wanderer. But really we know Descartes only from his writings, including the correspondence that was so intimately related to his mathematical and philosophical works. Perhaps that should be enough.

A peculiar issue in the case of Descartes is the way in which the condemnation of Galileo in 1633 broke his life in two. No satisfactory explanation of his tenderness on this point is known. Most of what Descartes had composed before that event was published only posthumously, if at all, although much was rewritten into later works printed between 1637 and
1649. Descartes was thus 41 - and of course already well known in intellectual circles - before a word of his was printed, and perhaps the most important part of his intellectual biography lies in the story of unfinished drafts and projects, and in the way in which these contributed to his brief productive period and to the posthumous books. As the author emphasizes, however, Descartes' new intellectual explorations during the later period of his life were in "legitimatory metaphysics". In natural philosophy his creative work was over. "The condemnation raised the question of how natural philosophy was to be legitimated, and in particular how it could be raised above the level of the hypothetical." Galileo's misfortune led directly to philosophy three most famous words: Cogito ergo sum.

The connection is traced - and a major theme of this book epitomized - as follows: "The problem that Descartes started off with was that of building up a natural philosophy, mechanism, as a basis for a microcorpuscularian, hydrostatically/hydrodynamically modelled physics whose fortunes were inextricably tied to those of Copernicanism."

Stephen Gaukroger is an experienced and erudite writer on Descartes.

He has a complete mastery of the recent literature, and is at home equally in metaphysics, epistemology and natural philosophy. He offers reasoned argument against many conventional criticisms of Descartes, for example that his physics was derived from metaphysics. (His defence should, however, be read in the light of a later claim that Descartes "is able to establish (metaphysically) the unique legitimacy of a particular way of pursuing natural philosophy without raising a single natural-philosophical question".)

But as the quoted passages may indicate, this is not an easy book and there are many stones to catch the unguarded toe. What, for instance, is "hyperbolic doubt"? Historians of mathematics may shudder a little at a quasi-dismissal of the Géométrie as "cobbled-up" from Descartes' earlier writings on mathematics; yet his use of the "mesolabe compass" is well treated. Some passages must be pretty opaque to readers imperfectly familiar with the Cartesian canon and earlier scholarly discussions. Of more structural importance is the absence of a systematic assessment of Descartes' character as a man and a philosopher out of place in a philosophical study of Descartes' writings but appropriate in a biography. True, there are accounts (generally unflattering) of his treatment of, for example, Isaac Beeckman or Fermat. Descartes, totally unreceptive to criticism, was assured of the truth of an intellectual system that, as Gaukroger explains, was tightly interlocked (if not completely consistent on every point), asserting once that if the velocity of light were not infinite, as he supposed, then all his philosophy must be false. He often abused those who could not see as clearly as himself.

Yet for us too that philosophy is often impenetrable. Descartes was on the far side of the divide created by Newton between philosophy and science. He was also unashamedly theological in his metaphysics and epistemology - to the point, more than once, of having his cake and eating it (as he did also in making Earth a planet while not, by his definition, allowing it to move). Yet Gaukroger is surely right to treat Descartes as the first unambiguously modern philosopher. He steers firmly, if not always simply, through the complexities created by the pressures to which Descartes' thinking was subject; ending with Descartes' skull, chopped off 16 years after his death by a Swedish officer and now in the Musée de l'Homme in Paris.

A. Rupert Hall is at 14 Ball Lane, Tackley, Oxfordshire OX5 3AG, UK.

\section{New Journals}

This year, Nature's annual new journals review supplement will appear in the issue of 21 September. Publishers and learned societies are invited to submit journals for review, taking note of the following criteria:

- Journals that first appeared during or after June 1993 and issued at least four separate numbers by the end of April 1995 will be considered.

- Journals covering any aspect of science are eligible, although those dealing with clinical medicine and pure mathematics are excluded, as are publications of abstracts.

- Frequency of publication must be at least three times a year. The main language used must be English.

Translation journals in English are, of course, eligible.

Deadline for submission is the end of May.

When submitting journals for review, please send at least four different issues (the first, the most recent and any two others) of each title, together with full details of subscription rates (personal and institutional) and frequency of publication to: Peter Tallack, Nature, Macmillan Magazines Ltd, Porters South, Crinan Street, London N1 9SQ, UK. Tel: +44 (0)171 8434567. 